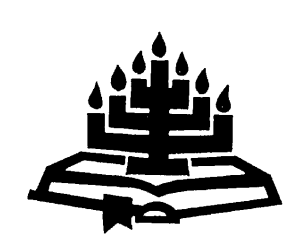

\title{
Die kerk en openbare beleidsvorming - 'n praktiese voorstel vir gereformeerde getuienis
}

\author{
N. Vorster
}

Navorser: Skool vir Kerkwetenskappe

Potchefstroomkampus

Noordwes-Universiteit

POTCHEFSTROOM

e-pos: nvorster@telkomsa.net

\begin{abstract}
Church and public policy - a practical model for reformed witness

The transition to a new constitutional dispensation in South Africa during 1994 has fundamentally changed the relation between church and state. The main differences between the old and new dispensation that have a direct influence on the public role of the church as institution are, inter alia, the following: the change from parliamentary sovereignty to constitutional supremacy, the change from a theocracy to a neutral state, and from a representative form of democracy to a participative form of democracy. The crucial question at this stage is: How should the church as institution fulfil its prophetic task towards society within the new constitutional context? This article attempts to answer the question by focusing on constitutional guarantees of religious rights, main principles for prophetic witness within a neutral state and pluralist society, and existing church structures for public engagement. The hypothesis of this article is that reformed churches should become involved in the legislative processes of the country by establishing a reformed monitoring body of legislation. This will be the most effective way of influencing public policy.
\end{abstract}

\section{Opsomming \\ Die kerk en openbare beleidsvorming - 'n praktiese voorstel vir gereformeerde getuienis}

Die oorgang tot 'n nuwe grondwetlike bedeling in Suid-Afrika in 1994 het die verhouding tussen kerk en die owerheid ingrypend 
verander. In die verandering na 'n nuwe bedeling is daar veral drie faktore wat 'n direkte invloed op die kerk het, naamlik die oorgang vanaf parlementêre soewereiniteit na grondwetlike oppergesag, vanaf 'n Christelike staat na 'n neutrale staat, en vanaf verteenwoordigende demokrasie na deelnemende demokrasie. Die kernvraag is: Hoe moet die kerk as instelling sy profetiese taak binne die konteks van die nuwe bedeling vervul? Die artikel probeer die vraag beantwoord deur te fokus op grondwetlike aanknopingspunte vir kerklike getuienis, belangrike beginsels vir profetiese getuienis binne 'n neutrale staat en 'n pluralistiese samelewing, en bestaande kerklike strukture wat die openbare mening kan beïnvloed. Die hipotese van hierdie artikel is dat reformatoriese kerke in Suid-Afrika betrokke moet raak by die wetgewende prosesse in die land deur 'n gereformeerde ekumeniese moniteringsliggaam tot stand te bring. Dit sal die mees effektiewe manier wees om openbare beleid te beïnvloed.

\section{Algemene oriëntering}

Artikel $28 \mathrm{KO}$ vereis van kerke 1 om profeties teenoor die owerheid te getuig. Die owerheid is immers ' $n$ instelling van God wat reg en orde moet handhaaf (Rom. 13:4, Artikel 36 NGB). Hoewel die Bybel nie 'n politieke handboek is wat spesifieke staatkundige modelle voorskryf nie, het die kerk die profetiese roeping om die beginsels wat politieke modelle ten grondslag lê en die wyse waarop die beginsels in die praktyk beslag kry, aan Bybelse beginsels en norme te meet (vgl. GKSA, 2003:83). Die taak van die kerk om die openbare mening te beïnvloed is nie net vanuit 'n teologiesprinsipiële hoek belangrik nie, maar ook vanuit 'n maatskaplike hoek. Die vigspandemie, hoë misdaadsyfer, armoede en die ongelykheid van die Suid-Afrikaanse samelewing maak morele leiding belangrik. Die vraag is egter hoe die kerk die openbare mening kan beïnvloed? Die radikaliteit van die transformasieproses waardeur Suid-Afrika ná apartheid gaan, hang grootliks daarmee saam dat die politieke, ekonomiese en sosiale vrugte van die Verligting feitlik oornag in Suid-Afrika geïnstitusionaliseer is. Die vraag na die openbare rol van die Christelike kerk het ingrypend en drasties verander (Smit, 1996b:193).

1 In hierdie artikel word die term kerk in sy amptelike institusionele betekenis gebruik. Die profetiese roeping van die kerk in die openbare lewe vertoon verskillende gestaltes. Hierdie artikel hanteer die profetiese roeping van die kerk in sy amptelike, institusionele hoedanigheid. 
In 1994 is 'n regstaat in Suid-Afrika gevestig wat 'n verskuiwing in die verhouding tussen die owerheid en kerke gebring het. Sedert 1994 het dit duidelik geword dat die tradisionele werkswyse wat deur die Gereformeerde Kerke in Suid-Afrika (voortaan GKSA) gevolg is om getuienis teenoor die owerheid te lewer, hersien moet word. Die Deputate vir Gesprek met die Owerheid het hieroor soos volg aan die 2003-Sinode van die GKSA verslag gedoen:

Dit het toenemend duidelik geword dat die tradisionele werkswyse wat tot 1994 deur die Deputate vir gesprek met die owerheid gevolg is, indringend hersien moes word. Dit het 'n uiters moeisame proses geword met soms twyfelagtige tot niksseggende eindresultaat. Die status en rol van die kerk in 'n gesekulariseerde samelewing wat gestruktureer word deur 'n vrye (liberale) demokrasie het verander (GKSA, 2003:83).

Om effektiewe getuienis met betrekking tot die owerheid te lewer sal kerke hulleself deeglik moet vergewis van die verskillende elemente en beginsels wat die nuwe regstaatbedeling in Suid-Afrika onderlê. Volgens Venter (1995:33) dui die konsep van 'n regstaat op 'n maatstaf waaraan die gebalanseerdheid, regverdigheid en effektiwiteit van 'n bepaalde staatkundige bestel gemeet word. Dit dui nie op ' $n$ vorm van regering nie, maar op die wyse waarop 'n land se regstelsel werk (Coetzee, 1995:33).

Le Roux (1994:56) gee die volgende omvattende beskrywing van 'n regstaat:

Die regstaat gee erkenning aan grondwetlike regering en die oppergesag van die reg. Dit beteken dat 'n owerheid se take deur regsvoorskrifte bepaal en afgebaken word. Terselfdertyd word die private en openbare vryhede en regte van elke individu beskerm, soos die vryheid van spraak, keuse van beweging en assosiasie sonder staatsinmenging. Die regstaat gee in 'n gedifferensieerde samelewing uitdrukking aan sowel politieke medeseggenskap deur individue as aan burgerlike owerhede. Voorts verskaf hy formele waarborge vir die verwesentliking van die regstaatbeginsel. Dit sluit in die skeiding van magte, regsbeskerming teen wanadministrasie, en onafhanklike regspraak en administrasie in ooreenstemming met die geskrewe wette van die Parlement.

Hoewel die 1996-Grondwet nie uitdruklik na Suid-Afrika as 'n regstaat verwys nie, is die beginsels en belangrikste elemente verbonde aan 'n regstaat in die finale Grondwet opgeneem in 'n direkte opdrag aan die grondwetskrywende vergadering. Reeds in 
1996 het die Konstitusionele Hof na die regstaatbeginsel verwys as die leidende beginsel van die 1996-Grondwet (Venter, 1997:75, 81).

Verskeie regstaatbeginsels word in die 1996-Grondwet gevind (vgl. Suid-Afrika, 1996):

- Artikel 1 (c) erken die oppergesag van die Grondwet, sowel as die heerskappy van die reg, as een van die grondwaardes van die Suid-Afrikaanse republiek.

- Artikel 8(1) bepaal dat fundamentele regte grondwetlik beskerm moet word deurdat die Handves van Regte van toepassing gemaak word op die totale reg. Die Handves van Regte bind die wetgewende, uitvoerende en regsprekende gesag, asook alle staatsinstellings. Regte kan alleen ingeperk word as die Grondwet dit goedkeur (Nathan, 1997:64)

- Artikel 165(2) maak voorsiening vir 'n onafhanklike regbank wat slegs aan die Grondwet en die reg onderworpe is.

- Artikel 1 (d) beskerm basiese demokratiese beginsels soos algemene stemreg, 'n nasionale kieserslys, gereelde verkiesings en ' $n$ veelpartystelsel van demokratiese regering, verantwoordingspligtigheid, 'n responsiewe ingesteldheid, en openheid as basiese grondwaardes van die Suid-Afrikaanse staat. Artikel 19 beskerm ook die politieke regte van alle burgers in Suid-Afrika.

- Die regsprekende, wetgewende en uitvoerende gesag word van mekaar geskei deurdat die regsprekende gesag aan 'n onafhanklike regbank opgedra word, die wetgewende gesag aan 'n parlement en die uitvoerende gesag aan 'n president (vgl. artikels 165(2), 44(4) en 83).

- Artikel 181(1 en 2) maak voorsiening vir onafhanklike meganismes ter ondersteuning van die grondwetlike demokrasie wat net aan die reg onderworpe is. Hierdie meganismes bestaan uit die Openbare Beskermer, Menseregtekommissie, die Kommissie vir die bevordering en beskerming van die regte van Kultuur-, Godsdiens-, en Taalgemeenskappe, die Kommissie vir Geslagsgelykheid, die Ouditeur-Generaal en die Verkiesingskommissie.

\section{Die verskuiwing in die verhouding tussen kerk en owerheid}

Wanneer die regstaatbedeling vergelyk word met die vorige politieke bedeling wat vanaf 1910-1994 gestrek het, kan enkele belangrike 
verskille aangetoon word wat in die toekoms vir die verhouding van die kerk met die owerheid van deurslaggewende belang kan wees.

\subsection{Parlementêre soewereiniteit en grondwetlike oppergesag}

Die grondwetlike reg van Suid-Afrika was in die tydperk van 19101994 hoofsaaklik gebaseer op Britse koloniale grondwetlike beginsels wat gedurende die 19de eeu ontstaan het en sederdien verder ontwikkel is (vgl. Venter, 1997:73). Die Parlement was in dié tydperk soewerein, met die gevolg dat die wetgewende proses nie gebonde was aan grondwetlike maatreëls en eksterne kontroles wat basiese menseregte beskerm het nie. Die Hooggeregshof kon wel die prosedures van grondwetlike wetgewende prosesse toets, maar die wette van die Parlement kon nie getoets word nie, met die gevolg dat die Parlement soewerein gebly het (Basson, 1995:17). Die regsinstellings van die staat was grootliks onmagtig om die wetgewende aanslag op menseregte te keer (Basson, 1995:17).

Die 1910-Grondwet het voorsiening gemaak vir 'n eenheidstaat wat uit vier provinsies bestaan het. Die staat is regeer deur 'n nasionale kabinet wat 'n soewereine parlement beheer het volgens die Westminsterstelsel (Venter, 1997:54). Die Parlement het bestaan uit 'n Volksraad en Senaat (Eybers, 1918:ixxix). Die uitvoerende gesag was verantwoordbaar aan die Volksraad sodat daar nie 'n skeiding van magte was nie (Thompson, 1990:150). Wette wat die Grondwet verander, kon op dieselfde wyse geïmplementeer word as enige ander wette (vgl. Thompson, 1990:150). Howe kon nie die geldigheid van besluite van die soewereine Parlement toets nie, met die gevolg dat die Parlement soewerein gebly het. Die wetgewende prosesse was bo eksterne kontrole verhewe, sodat dit 'n magtige instrument in die hande van die Kabinet onder leiding van die Eerste Minister geword het (Venter, 1995:135).

In die periode vanaf 1910-1948 het die Parlement deur die statutêre implementering van 'n segregasiebeleid sistematies op grond van ras en kleur teen groepe mense in Suid-Afrika gediskrimineer, sonder dat die bevolking hulleself op enige regskanale wat menseregte beskerm, kon beroep. Die segregasiebeleid was 'n ideologiese en wetgewende stelsel wat gepoog het om blanke heerskappy binne ' $n$ heterogene en veelrassige samelewing, wat toenemend besig was om te industrialiseer, te handhaaf en te verseker (vgl. Vorster, 2002:71). Swart mense se reg op grond is as voorwaardelik gesien en die blanke is as voog van swart mense aangestel. Die Segregasiebeleid is gekenmerk deur diskriminasie en die legitimering van sosiale ongelykheid op verskeie samelewingsvlakke, 
sodat dit nie net 'n territoriale beleid was nie, maar ook 'n diskriminerende ideologiese stelsel wat alle segmente van die samelewing geraak het (vgl. Dubow, 1989:1). Teen die tyd van die Tweede Wêreldoorlog het die segregasiebeleid begin verkrummel. Die etniese mobilisering van Afrikaners om hulle ekonomiese, kulturele en politieke belange te dien sou egter lei tot die oorname van die Gesuiwerde Nasionale Party in 1948 en 'n meer rigiede politieke stelsel van rassediskriminasie vanaf 1948 (Vorster, 2002: 89).

Vanaf 1948 is die apartheidsbeleid geïmplementeer. Die beleid van apartheid was 'n meer rigiede vorm van segregasie wat aan die een kant gekenmerk is deur sosiale en politieke skeiding, maar aan die ander kant deur groter ekonomiese integrasie. Die apartheidsbeleid het deur diskriminerende wetgewing probeer om wit heerskappy te handhaaf en te konsolideer, die suiwerheid van die wit ras te verseker en om die ekonomiese belange van die wit bevolking te dien (Vorster, 2002:89). Apartheid is deur die na-oorlogse wêreld as een van die mees diskriminerende politieke stelsels van die tyd beskou en is vanaf die sestigerjare aktief bestry met ekonomiese sanksies en internasionale isolasie. Die WVK-verslag noem die beleid van apartheid op sigself 'n menseregteskending:

... the policy of Apartheid was itself a human rights violation. The determination of an individual's civil and political rights by a factor - skin colour - over which he or she has no control, constitutes an abuse of those rights (TRC 1998, I:29).

In 1961 is 'n nuwe grondwet aanvaar wat die era van geïnstitusionaliseerde afsonderlike ontwikkeling ingelei het, waarvolgens vier etniese swart state en ses selfregerende gebiede ontwikkel is. Die res van die gebied is vir die blanke, kleurling- en Asiatiese bevolking gelaat (Venter, 1997:55). Die Westminsterbeginsels is onveranderd behou, met die gevolg dat die wetgewende en uitvoerende magsposisie van die Eerste Minister behou is (vgl. Venter, 1995:135). In 1983 is weereens 'n nuwe grondwet aanvaar waarin voorsiening gemaak is vir 'n nuwe driekamerparlement en 'n president met baie sterk uitvoerende magte. Die nuwe driekamerparlement was nog steeds soewerein, terwyl die kamer wat uit blankes bestaan het, vetoreg gehad het (vgl. Venter, 1997:55 en 1995:135). Namate die politieke situasie in Suid-Afrika versleg het, het die Parlement deur veiligheidswetgewing groter magte aan die uitvoerende gesag begin gee, sodat die Parlement eintlik sy eie soewereiniteit prysgegee het. 
Die feit dat die Parlement in die tydperk vanaf 1910-1994 soewerein was, het daartoe gelei dat rassistiese strukture sistematies gevestig kon word, en dat die regering in sosiale organisasies se sake kon inmeng (Van der Vyver, 1998:1). Kerke wat teen die apartheidsbeleid gekant was, het magteloos gestaan teen die statutêre aanslag op menseregte en was self die slagoffer van diskriminerende wetgewing en geweldadige staatsoptrede. Die bekendste voorbeelde hiervan was die sogenaamde Church Clause in die Wysigingswet op Swart Wetgewing (36/1957) wat aan die Minister van Samewerking en Ontwikkeling die reg gegee het om vanaf enige gegewe datum swart eredienste in wit gebiede te verbied as die publiek teen die samekomste beswaar maak. Verdere uitlopers van dié wet was die verbanning van die Christelike Instituut in 1977, die staatsbeplande aanval op die hoofkwartier van die SuidAfrikaanse Raad van Kerke in 1988 en die vernietiging van die hoofkwartiere van die Suid-Afrikaanse Katolieke Konferensie in dieselfde jaar (TRC, 1998, IV:75).

Met die totstandkoming van die Regstaat in 1994 het die Parlement sy bykans onbegrensde magte verloor. Die wetgewende gesag is ingevolge die 1996-Grondwet saam met die uitvoerende en regsprekende gesag gebonde aan 'n Handves van Regte (vgl. artikel 8(1)). Indien die Parlement wette sou maak wat strydig is met die Handves van Regte, kan die Grondwetlike Hof sodanige wette ongrondwetlik verklaar.

As regspersone is kerke geregtig op die regte in die Handves van Regte, met die gevolg dat kerke nie soos in die verlede magteloos hoef te staan teenoor onderdrukkende wetgewing wat uitgevaardig word nie (vgl. Artikel 8(4)). Kerke kan hulleself op hulle grondwetlikerkende regte beroep. Aan die ander kant word kerke as regspersone ook gebind aan die Handves van Regte. Die Handves van Regte het ingevolge artikel 8(2) 'n horisontale toepassing wat beteken dat individue nie net teen magsmisbruik deur die owerheid beskerm word nie, maar ook teen kollektiewe magsmisbruik deur ander instellings as die staat. Kerke kan gevolglik voor howe tot verantwoording geroep word oor menseregteskendings. Hieruit word dit duidelik dat die kerk se verhouding met die owerheid binne die konteks van 'n regstaat 'n sterker statutêre grondslag sal hê as in die vorige bedeling. Die kerk sal daarom binne die raamwerk van die Grondwet moet werk en kanale wat die regstaat bied, moet benut. 


\subsection{Christelike regering en neutrale regering}

Die vorige minderheidsregering het homself as ' $n$ voorstander van Christelike waardes beskou. In die inleiding van die 1983-Grondwet word gesê dat die Konstitusie probeer om Christelike waardes te handhaaf. Die owerheid se ideaal van 'n samelewing gebaseer op Christelike waardes het daartoe gelei dat die Christelike godsdiens voorkeurbehandeling bo ander godsdienste en waardestelsels geniet het. So het die Christelike godsdiens eksklusiewe toegang tot die aanbieding van godsdiensprogramme op televisie gehad - in bevoorregting bo ander godsdienste. Die Wet op Publikasies (42/74) het bepaal dat die Suid-Afrikaanse bevolking se Christelike lewensen wêreldbeskouing in die toepassing van die wet erken sal word. Die Wet op Nasionale Onderwysbeleid (39/67) het in seksie 2 (1a en b) bepaal dat wit kinders se onderrig Christelik-Nasionaal sou wees, en die Wet op Onderwys en Opleiding (90/79) het in seksie 3(a) bepaal dat swart kinders se onderrig Christelik sou wees sonder die nasionale komponent. Daar was ook 'n verskeidenheid van Sondagsonderhoudingstatute en provinsiale ordonnansies wat aan die een kant betrekking gehad het op sakeondernemings en aan die ander kant op vermaak en ontspanning (vgl. Van der Vyver, 1998:3 en Wet op die verbod op die vertoon van rolprente op Sondae en Openbare Vakansiedae 16/77). Die owerheid het verder die strafreg gebruik om sosiale euwels soos prostitusie, aborsie en dobbelary te bekamp.

Hoewel dit debatteerbaar is of die vorige owerheid met sy rekord van menseregteskendings werklik Christelike waardes gehandhaaf het, het die Christelike godsdiens voorkeurbehandeling bo ander godsdienste geniet. Die gevolg was dat veral die drie Afrikaanse hoofstroomkerke op 'n gemeenskaplike basis met die owerheid gesprek kon voer.

Een van die staande opdragte van die Nasionale Sinode van die GKSA aan sy Deputate vir Owerheidsake was dat dié deputate wetgewing moes dophou en in die lig van sinodebesluite moes optree. In die uitvoering van hierdie opdrag het die Deputate vir Gesprek met die Owerheid gereeld by die owerheid aangedring op wetgewing wat 'n Christelike lewens- en wêreldbeskouing bevorder. Die strafregtelike wetgewing waarop aangedring is, het praktyke soos handelsbedrywighede op Sondae, die keuring van immigrante, die toepassing van die Wet op Publikasies, asook die bestryding van onsedelikheid, owerspel en buite-egtelike verhoudings geraak (vgl. byvoorbeeld GKSA, 1964:517; 1988:464-481; 1991:661; 1994:567$568,581,584-585)$. Die owerheid het van sy kant dikwels skrywes 
gerig aan die Afrikaanse kerke waarin die kerke se raad oor bepaalde etiese sake gevra is (vgl. byvoorbeeld GKSA, 1976:467468). Afrikaanse kerke het verder 'n oop deur tot persoonlike gesprekke met die owerheid gehad. So het die Deputate vir Owerheidsake gereeld gesprekke met destydse Eerste Ministers gevoer waaroor aan die Nasionale Sinode verslag gedoen is (vgl. GKSA, 1979:299).

Binne die nuwe staatkundige bedeling bestaan die gemeenskaplike Christelike gespreksbasis tussen kerk en owerheid nie meer nie. Uit artikels 15(2) en 185 (1b) van die 1996-Grondwet kan afgelei word dat alle godsdienste deur die owerheid op 'n gelyke voet behandel moet word en dat die staat neutraal moet bly. Kerke kan daarom nie meer van die owerheid verwag om Christelike waardes deur wetgewing te beskerm of om 'n spesifieke Christelike moraliteit op die samelewing af te dwing nie, omdat dit die owerheid in stryd met die Grondwet sal bring. Die realiteit word weerspieël in die feit dat die owerheid nie meer die strafreg gebruik om Christelike samelewingswaardes te handhaaf nie. Onchristelike praktyke soos aborsie op aanvraag, volwasse pornografie en dobbelary is sedert 1994 deur die nuwe owerheid gewettig.

Selfs ten opsigte van gesprekke met die owerheid kan die kerk nie meer voorkeurbehandeling verwag nie. Die kerk sal sy profetiese roeping voortaan binne 'n konfessioneel-pluralistiese opset moet uitleef. In die Deputate vir Owerheidsake se verslag aan die Nasionale Sinode van die GKSA word gerapporteer dat die deputate nie suksesvol was in sy pogings om gesprek met die Staatspresident te voer nie: "Nadat oor die (nie) haalbaarheid van 'n gesprek met die President van die RSA besin is, is besef dat ander weë van kommunikasie met die owerheid gevind sal moet word" (GKSA, Agenda, 2003:82-83).

In die toekoms sal die President waarskynlik net met 'n gesamentlike liggaam bestaande uit verskillende godsdienste gesprek voer, en nie meer met verskillende denominasies nie.

Op grond van bogenoemde word dit duidelik dat die kerk binne die regstaatbedeling 'n nuwe gespreksbasis met die owerheid sal moet vind. Binne die regstaatbestel sal die Handves van Regte waarskynlik as die enigste gemeenskaplike basis vir gesprek kan dien, omdat die Handves van Regte die wetgewende, uitvoerende en regsprekende gesag aan bepaalde menseregtebeginsels bind. Kerke sal Christelike beginsels moet oor-"vertaal" in nie-religieuse taal. 
Sedert 1994 het die Suid-Afrikaanse howe in hulle grondwetlike regspraak hoofsaaklik aangesluit by die liberaal-Westerse tradisie se antroposentriese fundering van menseregte as die onvervreembare, aangebore en inherente besit van alle mense (vgl. Vorster, 2002:281). Hoewel daar onder die vernaamste teoloë en kerklike vergaderings binne die reformatoriese tradisie grootliks konsensus bestaan oor die feit dat die konsep van menseregte wel versoenbaar is met die Skrif, word eerder van Godgegewe as inherente, aangebore regte gepraat (vgl. RES, 1983:151-152; WARC, 1976:51 en Van Wyk 1991:254). Die feit dat die howe 'n liberale antroposentriese fundering aan die grondwaardes van die Grondwet gee, kan soos in die geval van die aanvaarding van die Wet op Keuse oor die Beëindiging van Swangerskap (92/96), probleme skep wat die soeke na 'n gemeenskaplike gespreksbasis tussen kerk en owerheid kan bemoeilik.

\subsection{Verteenwoordigende demokrasie en deelnemende demokrasie}

In 'n regstaatbestel val die onderskeid tussen owerheid en onderdaan weg, en word eerder gepraat van 'n burgery, want die staatkundige bestel bevat meganismes wat individue of groepe in staat stel om direk aan wetgewende prosesse deel te neem. Die klem val dus nie meer, soos vroeër, op verteenwoordigende demokrasie nie, maar wel op deelnemende demokrasie.

In ooreenstemming met die beginsel van deelnemende demokrasie maak die Grondwet voorsiening vir meganismes wat onafhanklik van die staat funksioneer, en wat net aan die reg onderworpe is. Hierdie meganismes sluit die volgende in: die Grondwetlike Hof, Menseregtekommissie, Openbare Beskermer, die Kommissie vir die bevordering en beskerming van die regte van Kultuur-, Godsdiens-, en Taalgemeenskappe, die Kommissie vir Geslagsgelykheid, die Ouditeur-Generaal en die Verkiesingskommissie. Die taak van hierdie meganismes is om by die owerheid en die burgerlike gemeenskap respek te skep vir die waardes van die Suid-Afrikaanse Grondwet (vgl. artikel 181 (1 en 2)). Die burgerlike gemeenskap kan hulleself op hierdie liggame beroep wanneer hulle regte aangetas word. Behalwe vir die onafhanklike meganismes ter ondersteuning van die grondwetlike demokrasie, vaardig die owerheid gereeld konsepwetgewing uit vir kommentaar deur die burgerlike gemeenskap. Op hierdie wyse word die burgerlike gemeenskap in staat gestel om direkte inspraak in wetgewende prosesse te kry. 
Die Deputate vir Owerheidsake het in sy 2003-rapport aan die Nasionale Sinode van die GKSA daarop gewys dat dit weinig sin vir die kerk het om, soos in die verlede, gesprekke met parlementslede of streeksverteenwoordigers te voer. Die strategie van inspraak by sogenaamde vriende in verantwoordelike kringe (soos in die vorige bedeling) is nie meer ' $n$ werkbare opsie nie (GKSA, 2003:84). Die Deputate stel daarom voor dat ander moontlikhede oorweeg moet word: die kerklike monitering van konsepwetgewing, die aanbied van kundigheid aan staatdepartemente wanneer konsepwetgewing opgestel word, en die daarstelling van 'n adviesgroep van Christenparlementariërs van reformatoriese belydenis wat aan kerke verslag doen (vgl. GKSA, 2003:85, 86).

Uit die 2003-rapport van die GKSA se Deputate vir Owerheidsake blyk dit duidelik dat die vraag na die praktiese wyse van kerklike getuienis binne die Suid-Afrikaanse regstaat, spesifiek met betrekking tot die owerheid, baie aktueel is. Die vraag wat in hierdie artikel aan die orde kom, is die volgende: Watter praktiese model moet die kerk volg om sy profetiese roeping teenoor die owerheid en samelewing na te kom binne die konteks van 'n regstaat en 'n sosiaal- en konfessioneel-pluralistiese samelewing? Hierdie vraag sal vervolgens beantwoord word deur te fokus op die volgende: moontlike grondwetlike aanknopingspunte vir getuienis, belangrike beginsels vir profetiese getuienis binne 'n neutrale staatsverband en pluralistiese samelewing, bestaande kanale vir profetiese getuienis, en 'n moontlike model vir die kerklike monitering van wetgewing.

\section{Grondwetlike aanknopingspunte vir kerklike getuienis}

Die formele skeiding tussen kerk en staat in 'n polities-liberale bestel en die grondwetlike erkenning van religieuse pluralisme het dikwels die gevolg dat kerklike getuienis tot die private sfeer beperk word en dat kerke dit moeilik vind om die openbare mening te beïnvloed. Die Verenigde State van Amerika is 'n goeie voorbeeld van 'n land waar die absolute skeiding tussen godsdiens en staat feitlik tot die negering van 'n openbare rol vir godsdiens lei.

Die Amerikaanse Grondwet bevat in die eerste Amendement wat oor godsdiensvryheid handel, sowel 'n sogenaamde free exercise clause as 'n establishment clause. Die free exercise clause verbied die staat om gewetensdwang op aanhangers van godsdienstige oortuigings toe te pas. Dit vind, volgens die American Supreme Court, alleen plaas wanneer van iemand vereis word om teenstrydig met sy godsdienstige oortuigings op te tree. As 'n wet 'n religieus- 
neutrale impak het, hoef 'n beperking op religieuse optrede nie geregverdig te word nie (Pieterse, 2000:303-304). Die establishment clause weer verbied die staat om direk of indirek bepaalde godsdienste of godsdienstige oortuigings te bevorder. Dit probeer om 'n skeiding tusssen kerk en staat te handhaaf sodat godsdienstige oortuigings nie op burgers afgedwing word nie. Terselftertyd poog dit om die gelykheid tussen godsdienste te handhaaf (vgl. Pieterse, 2000:303). Volgens Witte (1993:21-22) was die oorspronklike bedoeling van hierdie twee klousules om godsdiensvryheid te beskerm. Die Amerikaanse howe het egter die klousules teenoor mekaar gaan stel, in plaas daarvan om dit te gebruik as gesamentlike waarborge vir godsdiensvryheid. Die gevolg was dat die beginsel van 'n skeiding tussen kerk en staat 'n instrument geword het waardeur godsdiens geprivatiseer en gemarginaliseer word.

Die Suid-Afrikaanse Grondwet bevat nie 'n eksplisiete establishment clause nie en handhaaf daarom ook geen absolute skeiding tussen godsdiens en staat nie (vgl. Henrard, 2001:54). In die saak State $v$ Lawrence is die afwesigheid van 'n establishment clause deur die Grondwetlike Hof bevestig. Vier regters het gemaan dat 'n establishment clause nie in die Grondwet ingelees moet word, soos in die geval van die Amerikaanse Grondwet nie (vgl. Ackermann, 2002:181, Venter, 1998:457). Volgens regter Ackermann (2002: 178) probeer die Grondwet duidelik om nie 'n muur tussen staat en godsdiens op te rig nie. Inderwaarheid erken en ondersteun die Grondwet die belangrike rol wat godsdiens in die samelewing speel (Gildenhuys, 2002:200). Dit word bevestig deur die volgende opmerkings van regter Sachs in Christian Education South Africa $v$ Minister of Education [par 33]:

Religion is not always merely a matter of private individual conscience or communal sectarian practice ... Many major religions regard it as part of their spiritual vocation to be active in the broader society ... Religion is not just a question of belief or doctrine. It is part of a way of life, of a people's temper and culture.

Die afwesigheid van 'n establishment clause in die Suid-Afrikaanse Grondwet word bevestig deur artikel 15 (2) van die 1996-Grondwet wat ruimte laat vir die beoefening van godsdiens by staatsskole. Artikel 15(3) weer beskerm die regte van godsdienstige minderheidsgroepe deur voorsiening te maak vir huwelike wat ooreenkomstig godsdienstige reg aangegaan word, asook stelsels van persone- en gesinsreg wat gevolg word deur persone wat 'n bepaalde godsdiens aanhang. Daarbenewens beskerm die Grond- 
wet indirek en direk kommunale aspekte van godsdiensbeoefening (Ackermann, 2002:178). Artikel 18(1) beskerm kommunale en institusionele aspekte indirek deur die reg tot vryheid van assosiasie te beskerm en artikel 31 beskerm dit direk deur die regte van kulturele, godsdienstige en taalgemeenskappe te erken. Daar is ook ander artikels in die Grondwet wat van toepassing is op die openbare rol van godsdiens. Artikel 16 waarborg die vryheid van uitdrukking, waaronder die vryheid om idees of inligting te ontvang en oor te dra, die reg op akademiese vryheid, en vryheid tot wetenskaplike navorsing. Hierdie artikel maak dit vir godsdienstige gemeenskappe moontlik om sosiale en politieke strukture en beleid te kritiseer in terme van die dogma van sodanige godsdienste (vgl. Du Plessis, 1994:166). Artikel 17 weer beskerm die reg om vreedsaam te vergader. Artikel 19 beskerm die reg om 'n politieke party te kan vorm, wat ook Christelike partye kan insluit, en artikel 29(3) beskerm die reg om godsdiensonderrig te gee by private onderwysinstellings.

Uit die aard van die saak kan gevalle voorkom waar die openbare rol van godsdiens in gedrang kan kom. Die afwesigheid van 'n establishment clause beteken nie dat die staat vrylik in godsdienstige aangeleenthede kan inmeng of vrylik alle religieuse praktyke kan ondersteun nie (Gildenhuys, 2002:202). Die reg tot godsdiensvryheid sal in gedrang kom wanneer die staat se ondersteuning van godsdiens daarop neerkom dat persone gedwing word om hulle godsdienstige oortuigings te verander of wanneer die staat se ondersteuning van godsdiens daarop neerkom dat tussen persone gedifferensieer word op grond van hulle godsdiens. Wanneer die gelyke beskerming van alle godsdienste voor die reg in gedrang kom, kan die gelykheidsklousule ook in gedrang kom (Pieterse, 2000:309). Verder moet in gedagte gehou word dat al die artikels $(15(2), 16,31)$ wat 'n openbare plek aan godsdiens toeken, interne beperkingsklousules bevat, wat beteken dat hierdie regte ingeperk kan word sonder die noodsaaklikheidsvereiste van artikel 36 (vgl. Pieterse, 2000:316). Sodanige inperkings sal egter net plaasvind wanneer openbare orde en die vreedsame naasbestaan van landsburgers in gedrang kom.

Behalwe vir bogenoemde artikels word die Suid-Afrikaanse staat in die aanhef van die Grondwet beskryf as 'n oop en demokratiese samelewing. Openheid impliseer dat openbare beleid rasioneel geregverdig moet kan word en dat sosiale groepe 'n geleentheid moet hê om ' $\mathrm{n}$ rol te kan speel in openbare beleidsvorming. Daarom word konsepwetgewing vir kommentaar aan die burgerlike 
gemeenskap voorgelê. Dit dien as 'n belangrike aanknopingspunt vir die kerk om 'n rol te speel in openbare beleidsvorming.

Uit bogenoemde kan afgelei word dat die nuwe Grondwet voldoende ruimte bied vir die kerk om 'n openbare en kritiese rol te vervul. Die kerk sal egter moet besef dat dit nie voorkeurbehandeling ten koste van ander godsdienste kan verwag nie. Die nuwe Grondwet beskerm religieuse pluraliteit en diversiteit soos duidelik blyk uit artikels 6 (5)(b) (ii) en 15(3) (vgl. Gildenhuys, 2002:129). Verder stel die Grondwet sigself ten doel om verdraagsaamheid tussen SuidAfrikaners te bevorder deur individue en groepe met botsende belange te versoen (vgl. aanhef waar gestel word dat die Grondwet die verdeeldheid van die verlede probeer oorkom). Die kerk sal binne 'n pluralistiese opset sy bydrae moet lewer.

\section{Kernbeginsels vir profetiese getuienis ${ }^{2}$}

Die Amerikaanse etikus, Gustafson (1988:268-270), onderskei tussen vier vorme van kerklike morele diskoers met betrekking tot die openbare lewe, naamlik die profetiese, narratiewe, etiese en beleidsdiskoerse. Onder profetiese diskoers verstaan hy twee hoofelemente. Die eerste element is morele en religieuse aanklagte. Oorsake vir afval in die samelewing word geïdentifiseer en sterk veroordeel. Die tweede element is dat 'n ideaal geïdentifiseer word wat op 'n utopiese wyse aan die samelewing voorgehou word as iets om na te streef. Die narratiewe diskoers gebruik verhale om die religieuse en morele identiteit van 'n spesifieke gemeenskap te vorm. Deur verhale te vertel word 'n bepaalde groeps-etos gevorm. Dit is egter alleen effektief binne homogene gemeenskappe wat gemeenskaplike ervarings deel. Etiese diskoers gebruik filosofiese vorme van argumentasie en analise. Dit word gekenmerk deur presiese omskrywings van begrippe soos geregtigheid, regte, pligte, ensovoorts, asook 'n logiese vorm van argumentasie. Beleidsdiskoers formuleer weer die beleid wat verkieslik is binne bepaalde historiese omstandighede. Dit word gewoonlik gedoen deur persone wat verantwoordelike posisies van mag beklee.

Verskillende vorme van morele diskoers sal in verskillende situasies gebruik word. Die vorm van diskoers wat gebruik word, behoort verder ingeklee te word deur morele beginsels wat vertrekpunte en riglyne vir getuienis verskaf. Die volgende beginsels sal in die

2 Vir 'n uitvoerige prinsipiële bespreking van die verhouding tussen kerk en owerheid vergelyk Vorster (2002). 
toekoms belangrik wees vir effektiewe getuienis teenoor die owerheid.

\subsection{Moreel-etiese getuienis}

Dit is belangrik dat die kerk in die uitvoering van sy profetiese taak sy eie unieke aard moet behou. Kuitert (1985:227) wys tereg daarop dat hoewel God met alle dinge te doen het, teologie nie alles weet nie. Die kerk is doodgewoon nie toegerus om alle politieke, ekonomiese en juridiese aangeleenthede te hanteer nie. Hoe meer die kerk op terreine van ander dissiplines beweeg, hoe weerloser en ongeloofwaardiger word die stem van die kerk.

Aan die ander kant is dit belangrik dat die kerk nie uit die openbare lewe geweer moet word nie. Christus se koningskap strek nie net oor die kerk nie, maar oor alle aspekte van die lewe (vgl. Kol.1:18). Aardse gesag staan in diens van God se gesag en mag daarom nooit verabsoluteer word nie. Juis daarom het die kerk 'n profetiese taak teenoor die owerheid en is die lewenswyse van gelowiges nooit sonder politieke betekenis nie (vgl. Smit \& De Villiers, 1995:45). In Europa het die absolute skeiding tussen kerk en staat nie net die kerk gemarginaliseer nie, maar ook bygedra tot morele deformasie in die Europese samelewing. Die marginalisering van die kerk het gedeeltelik aanleiding gegee tot die verbrokkeling van gesinswaardes en die geleidelike vernietiging van familienetwerke. In 'n insiggewende studie deur Wiher (2002) word aangetoon dat die skuldkultuur wat vroeër in Christelike Europa bestaan het, stelselmatig as gevolg van sekularisasie plek maak vir 'n skaamtekultuur. Omdat jongmense in Europa nie meer vashou aan godsdienstige waardes en Goddelike regverdigheid nie, ervaar hulle nie meer skuldgevoelens oor verkeerde dade nie, maar alleen skaamte wanneer hulle uitgevang word. Die kerk is een van die min gemeenskappe waarin mense geskool word om vanuit 'n beginselbasis goeie en ordentlike burgers van die samelewing te wees (vgl. Smit, 1996a:123). Tereg stel Smit (1996b:196) dat moraliteit gevorm en gekweek moet word. Daar is egter instellings in die samelewing nodig waar morele vorming kan plaasvind. Juis as gevolg van sy eie aard en roeping kan die kerk die politieke sfeer nie aan die owerheid alleen oorlaat nie. Die owerheid beïnvloed immers die gehalte van mense se lewens en die kerk het die roeping om daarby betrokke te wees (Smit, 1996b:194).

Die kerk behoort egter in die openbare domein sy fokus te beperk tot religieuse en moreel-etiese aangeleenthede. Christus gee aan die kerk die sleutels van die koninkryk wat uit die bediening van die 
Woord en tug bestaan (vgl. Matt. 16). Die kerk se mag is daarom uitsluitlik geestelik van aard. Dit is noodsaaklik dat die kerk nie vir homself politieke mag probeer toeëien of dat die kerklike lewe moet opgaan in sosiale en politieke aksies nie.

Teenoor Kuyper wat meen dat die kerk in sy institutêre vorm alleenlik sy eie identiteit kan prysgee deur betrokkenheid in die openbare domein, moet gestel word dat die formulering van openbare beleid en wetgewing altyd bepaalde etiese aspekte impliseer. Dit gaan immers in openbare beleid oor perspektiewe op die gemeenskaplik goeie (vgl. Cochrane, 1997:6). Agter objektiewe ekonomiese en politieke strukture staan lewens- en wêreldbeskouings wat koherensie en rigting gee aan daardie strukture (vgl. Cochrane, 1997:9). Vrae oor moraliteit, mensbeskouing, botsing van morele pligte, grense vir magsuitoefening, die ekonomies impak van wetgewing, ensovoorts is inherent deel van die problematiek in openbare beleidsvorming en dit raak die kerk op 'n direkte wyse. Kerke kan daarom in openbare beleidsvorming 'n belangrike rol speel sonder om sy eie identiteit prys te gee. Die kerk behoort immers vanuit sy eie evangeliese verstaan van geregtigheid vir gestaltes daarvan in die samelewing te stry (vgl. Smit, 1996b:200).

\subsection{Solidêr-kritiese getuienis}

Met solidêr word bedoel dat die kerk die welsyn van die breë gemeenskap moet dien. Kerke moet nie verskraalde seksionele belange of die eiesoortige politieke belange van hulle lidmate dien nie. Die geloofwaardigheid van die kerk bestaan juis daarin dat die kerk, in teenstelling met teenoorstaande politieke partye, mag nie moet nastreef of selfsugtige politieke gewin soek nie. Smit en De Villiers (1995:45) stel tereg dat die samelewing en die staat daarvan afhanklik is dat aan die dialoog tussen sosiale magsgroepe ook partye deelneem wat geen direkte eiebelang het by die uitkomste daarvan nie. 'n Belangrike deel van die solidêre benadering van die kerk behoort juis die soeke na versoening tussen verskillende sosiale groepe te wees.

Met krities word bedoel dat die kerk sigself nie met politieke ideologieë moet kompromiteer nie. Suid-Afrika se verlede is 'n goeie bewys van die gevare van 'n onkritiese verhouding tussen kerk en staat. In Suid-Afrika bly dit 'n wesenlike gevaar dat die kerk ingespan kan word om 'n burgerlike godsdiens van nasiebou en versoening te dien. Deur 'n kritiese rol te vervul, kan die kerk 'n belangrike rol as waghond speel deur toe te sien dat die owerheid sy mag nie misbruik nie. 


\subsection{Transendente en immanente getuienis}

'n Onderskeid moet getref word tussen transendente en immanente profetiese kritiek. Onder transendente kritiek word verstaan 'n vorm van kritiek wat ander denkstelsels vanuit die eie denkstelsel kritiseer. Immanente kritiek, daarenteen, is 'n vorm van kritiek wat ander denkstelsels binnedring en sekere anomalieë in die denkstelsel uitwys deur met die ander denkstelsel in die taal van daardie denkstelsel te kommunikeer. Die etiese diskoers se filosofiese vorme van argumentasie, presisie van konsepte en logiese denke sal veral in hierdie opsig ter sprake kom.

Wanneer persone of groepe persone vanuit verskillende paradigmas met mekaar redeneer, is 'n immanente vorm van kritiek meer effektief as 'n transendente vorm van kritiek (vgl. Vorster, 2003:111). Binne 'n sekularistiese en pluralistiese samelewing waar baie mense vervreem is van die Christelike tradisie, sal religieuse taal dikwels 'n ontoereikende uitwerking hê. Dit is daarom nodig dat die kerk soms Christelike beginsels in nie-religieuse taal moet hervertaal. 'n Moontlike aanknopingspunt vir gesprek met die owerheid en samelewing kan die grondwaardes van die Grondwet wees, naamlik menswaardigheid, gelykheid en vryheid. Kerke sal op die gebreke van die Westerse liberale siening van menswaardigheid, gelykheid en vryheid moet wys en 'n Christelike inhoud aan hierdie waardes moet gee sonder om dogmatiese kerklike taal te gebruik. Teenoor die sterk individualistiese inkleding wat die Westerse verstaan aan hierdie waardes gee, kan die Christelike verstaan van hierdie waardes 'n groter klem op roeping, plig en verantwoordelikheid teenoor die gemeenskap plaas - aspekte wat noodsaaklik is vir die heropbou en ontwikkeling van Suid-Afrika (vgl. Vorster, 2002:227346).

\subsection{Ontmitologiserende getuienis}

Politiek bevat in sy wese 'n sterk ideologiese komponent. Met ideologie word bedoel dat politieke groepe dikwels 'n karikatuur van politieke opponente maak en daardie karikature beveg in retoriese taal wat polariseer. Terselftertyd word mites aangaande die self geformuleer en gepropageer deurdat politieke groepe hulle eie belange as moreel regverdigbaar en in die belang van die breë gemeenskap voorhou, en hulle partybeleid as 'n verlossingsboodskap vir almal (vgl. ook De Villiers, 1999:78). Hierdie ideologiese komponent van politiek kom gewoonlik sterk na vore in totalitêre state, maar kan ook in 'n mindere of 'n meerdere mate in selfs die mees ontwikkelde demokratiese state voorkom. 
Politieke ideologie is gevaarlik omdat dit groepe mense dikwels polariseer deur die opponent te demoniseer. In hierdie verband kan die kerk help om die politieke arena te ontmitologiseer deur die profetiese diskoers se vorm van aanklag en veroordeling te gebruik. Die kerk staan immers in diens van die waarheid en liefde. Leuenagtige retoriek, polariserende taal en die verdemonisering van opponente moet beveg word deurdat kerke krities met sulke groepe in gesprek tree of amptelike verklarings in dié verband uitreik. Natuurlik sal die kerk slegs in uiterste situasies waar versoening en verdraagsaamheid in gedrang kom, moet optree. Kerke sal in hierdie verband ook krities na hulle eie ideologiese voorveronderstellings moet kyk.

\subsection{Ekumeniese en evangeliese getuienis}

Uit die aard van die saak word die verkondigingstaak van die kerk nie alleen deur amptelike instansies vervul nie. In eredienste, gemeentelike byeenkomste, in fakulteite, in die betrokkenheid van lidmate by die samelewing geskied hierdie verkondiging (vgl. Smit \& De Villiers, 1995:46). Eenstemmige amptelike getuienis bly egter 'n ideaal waarna gestreef moet word - nie omdat dit noodwendig meer evangeliese gesag dra as die getuienis van gemeentes, individue of kleiner groepe nie, maar omdat dit die bedingingsmag van die kerk in die openbare lewe versterk (vgl. Smit \& De Villiers, 1995:47). Dit is daarom noodsaaklik dat kerke onderling moet streef na eenstemmige ekumeniese getuienis. Verdeelde getuienis is swak getuienis en gee aan owerhede die geleentheid om verskillende kerklike standpunte teenoor mekaar af te speel. 'n Verdere waarde van ' $n$ ekumeniese benadering is dat dit die kwaliteit van kerklike getuienis kan verhoog omdat 'n verskeidenheid mense en perspektiewe betrek word. Daarbenewens kan 'n ekumeniese benadering keer dat kerklike uitsprake oor openbare aangeleenthede ideologies gekleur word.

Terselfdertyd moet die getuienis van die kerk evangeliese gesag bevat. Dit beteken dat die beginsels, norme en waardes wat verkondig word, in ooreenstemming moet wees met die evangelie. Wanneer die kerk beginsels vreemd aan die Skrif begin verkondig, word die eiesoortige, unieke aard van die kerk in gevaar gestel. Ervaring uit die kerkgeskiedenis leer dat dit dikwels moeilik is om ekumenies op 'n evangeliese wyse te getuig omdat kerke se verstaan van die aard van die gesag van die Skrif verskil. Desnieteenstaande is daar baie sake van openbare belang waaroor die 
grootste meerderheid van kerke saamstem. Kerke sal dalk minder op verskille en meer op ooreenkomste moet fokus.

\subsection{Transkulturele getuienis}

Nie net die Suid-Afrikaanse samelewing nie, maar ook die kerk is 'n pluralistiese verskynsel. In die apostolicum, die mees ekumeniese belydenis, word juis die algemeenheid van die kerk bely. Daarmee word erken dat die kerk nie beperk is tot bepaalde groepe en tale nie, maar dat dit die grense van volk, taal en nasie oorskry. Binne die Suid-Afrikaanse konteks is gesamentlike transkulturele profetiese getuienis om twee redes van deurslaggewende belang. In die eerste plek kan dit kerke in staat stel om 'n meer gebalanseerde perspektief op ons samelewing te ontwikkel en om gebalanseerde getuienis teenoor die owerheid te lewer sonder om die belange van bepaalde bevolkingsgroepe voorop te stel ten koste van ander. Tydens die gesprek van die Afrikaanse kerke met die ANC op 7 Oktober 2003 was dit opvallend dat die probleme waaroor gepraat is, hoofsaaklik wit problematiek was. Tweedens sal transkulturele getuienis meer gesag dra en as meer geloofwaardig in regeringskringe ontvang word. Dit is geen geheim dat Afrikaanse kerke se ondersteuning van apartheid in sommige gevalle en stilswye in ander gevalle, die geloofwaardigheid van hierdie kerke ernstig aangetas het nie. Transkulturele getuienis saam met swart kerke kan groter geloofwaardigheid aan die getuienis van veral Afrikaanse kerke gee. Terselfdertyd is dit belangrik dat alle kerke voor hulle eie deur moet vee met betrekking tot rasse-aangeleenthede.

\subsection{Lokale en nasionale getuienis}

Min nie-regeringsorganisasies het dieselfde vermoë as die kerk om tot feitlik elke plaaslike gemeenskap uit te reik (vgl. Cochrane, 1997:4). Plaaslike regering in Suid-Afrika word dikwels, veral in landelike gebiede, gekenmerk deur 'n gebrek aan kundigheid, logistieke vermoëns, kommunikasievaardighede, werksetiek, ensovoorts. Dit is belangrik dat kerke met plaaslike owerhede moet kommunikeer en positiewe morele leiding aan plaaslike amptenare moet gee deur byvoorbeeld soms afgevaardigdes na gemeenskapsforums te stuur en gemeenskapsleiers te ontvang. Plaaslike kerke kan op so 'n wyse baie bydra tot versoening in Suid-Afrika. Tydens die gesprek wat afvaardigings vanuit die Afrikaanse kerke met lede van die uitvoerende komitee van die ANC op 7 Oktober 2003 gehad het, het die ANC die noodsaaklikheid van kerklike betrokkenheid by plaaslike regeringsaangeleenthede beklemtoon. 


\section{Bestaande kerklike strukture vir betrokkenheid in openbare meningsvorming}

Die meeste kerke het deputate, kommisies of skakelpersone vir owerheidsake. Dit is egter vanweë reeds genoemde redes 'n ope vraag of sulke tradisionele kerklike strukture werklik 'n invloed op openbare meningsvorming kan uitoefen. Tans is daar enkele kerklike liggame in Suid-Afrika wat op meer konstruktiewe wyses openbare beleidsvorming probeer beïnvloed, naamlik die parlementêre lessenaar van die Nederduitse Gereformeerde Kerk (voortaan die NG kerk), die Konvent van Reformatoriese Kerke in SuiderAfrika, die National Religious Forum, die parlementêre kantoor van die Suid-Afrikaanse Raad van Kerke, en die Rooms-Katolieke Biskopperaad se parlementêre kantoor.

Die parlementêre lessenaar van die NG kerk is verantwoordelik aan die Algemene Sinodale Kommissie en die moderamen van die WesKaapse sinode as opdraggewende instansies en doen verslag aan hulle op ' $n$ gereelde basis. Dit geskied in samewerking met die Direkteur vir Inligting van die Algemene Sinode (Du Toit, 2003:1). Die Gereformeerde Kerke se Deputate vir Owerheidsake het onder leiding van dr. Pieter Bingle ook 'n belangrike rol gespeel in die vestiging van die lessenaar (GKSA, 2003:217). Die lessenaar kommunikeer met die skribas van die verskillende sinodes oor alle relevante sake voortvloeiend uit die wetgewende proses en hanteer ook alle navrae uit verskeie oorde oor wetgewing (Du Toit, 2003:1). Die missie van die parlementêre lessenaar is om saam met ander Christelike rolspelers toepaslike bydraes te lewer in die formulering van wetgewing, sodat die wetgewende proses voortdurend onderwerp kan word aan die lig van God se Woord (Du Toit, 2003: 2). Die lessenaar se doelwitte is gefokus op die volgende:

- Die beskerming van godsdiensvryheid, die reg van die individu en die vryheid van spraak.

- Die beskerming van die regte van minderbevoorregtes.

- Die beskerming van kinders, die bevordering van 'n gesonde gesinslewe en die daarstelling van 'n gemeenskaplike morele waardestelsel vir die versekering van 'n regverdige en opbouende samelewing in Suid-Afrika en die beskerming van basiese regte soos gesondheid en onderwys.

- Die beywering vir die vrede en sekuriteit van alle mense.

- Die versekering van 'n veilige konteks vir die voortbestaan van die kerk in Suid-Afrika. 
Die lessenaar probeer met ander kerklike groepe soos die SuidAfrikaanse Raad van Kerke en die Katolieke Biskopperaad saamwerk, terwyl daar saam met die Gereformeerde Kerke en die Nederduitse Gereformeerde Kerk 'n adviesgroep van parlementariërs saamgeroep is om mekaar wedersyds te adviseer ten opsigte van wetgewing wat geprosesseer word. Verantwoordelike persone is vir hierdie doel deur die genoemde kerke aangewys.

Die Konvent van Reformatoriese Kerke in Suider Afrika reël byeenkomste waartydens kerke gemeenskaplike sake op grond van die reformatoriese belydenis bespreek in ooreenstemming met elke kerk se eie aard, etos en geskiedenis. Die Konvent se oogmerk is om gemeenskaplike getuienisse op grond van die Skrif en die reformatoriese belydenis te lewer in die Suid-Afrikaanse en moontlik Suider-Afrikaanse samelewings, veral ten opsigte van die betrokke owerhede. Die doel van die Konvent is nie om in die beleidmakende prosesse van die land betrokke te raak nie, maar wel om by wyse van verklarings te getuig op 'n gereformeerde ekumeniese grondslag (Konvent van Reformatoriese Kerke, 1998:1-2).

Die parlementêre kantore van die Suid-Afrikaanse Raad van Kerke en die Rooms-Katolieke Biskopperaad fokus meer spesifiek op die kerklike monitering van wetgewing. Die Suid-Afrikaanse Raad van Kerke het twee voltydse poste, en die Rooms-Katolieke Biskopperaad drie poste (waaronder een regsgeleerde) wat voltydse monitering van wetgewing doen. Die parlementêre kantoor van die Suid-Afrikaanse Raad van Kerke fokus op die monitering van wetgewing en staatsbeleid, lewer inspraak by sake wat kerke raak, gee inligting deur aan kerklike organisasies oor huidige beleidsdebatte, bied werkswinkels aan, en gee pastorale hulp aan parlementslede. Monitering van wetgewing word gedoen deur personeel wat parlementêre komiteevergaderings, werkswinkels en strategiese beplanningsvergadering met burgerlike organisasies bywoon en staatsverslae en dokumente analiseer. Inspraak word gelewer deur voorleggings aan die Parlement en staatsdepartemente te maak. Die kantoor fasiliteer verdere inspraak van kerklike liggame deur gereelde verslae oor die status van nasionale wetgewing en staatsregulasies te lewer (SACC, 2003:1).

Die National Religious Leaders Forum is ' $n$ intergodsdienstige liggaam wat tot stand gebkom het op aandrang van die voormalige Staatspresident dr. Nelson Mandela. Dit bestaan uit verskeie kerke, denominasies en gelowe. Hierdie liggaam ontmoet die president twee keer ' $n$ jaar waartydens gemeenskaplike sake van religieuse belang met die president bespreek word. Die liggaam is tot stand 
gebring op aandrang van die regering, omdat die regering verskillende kerklike standpunte verwarrend vind en graag wil hê dat die godsdienstige gemeenskap met een stem moet praat.

\section{6. 'n Moontlike praktiese model vir gereformeerde getuienis}

Vroeër in die artikel is reeds daarop gewys dat verskillende vorme van kerklike getuienis, asook verskillende moontlikhede vir kerklike getuienis bestaan met betrekking tot die openbare lewe. Binne die nuwe staatkundige bedeling wat die burgerlike gemeenskap betrek in beleidmakende en wetgewende prosesse sal die mees effektiewe vorm van getuienis gesetel wees in deelname aan beleidmakende prosesse. Amptelike verklarings van sinodes en kerklike liggame, dikwels nadat wetgewing goedgekeur is, het binne die nuwe staatkundige konteks weinig invloed op die formulering van openbare beleid. Openbare beleid word immers gevorm by wyse van dialoog tussen sosiale en politieke groepe. Die verskillende stappe in die proses van wetskrywing word soos volg deur Du Toit uiteengesit (2003:3-4) ${ }^{3}$ :

- Wette word verwys vir amendering of herskrywing, of kennis van nuwe wetgewing word gegee deur die kabinet, die parlemêre regskommissie of regeringsdepartemente.

- Die proses van wetskrywing volg die orde van 'n departementele groenskrif waarin 'n algemene aanduiding gegee word van die sake wat van toepassing is. Die verskillende alternatiewe word ter oorweging beskikbaar gestel en diskussie word uitgenooi. Hierna volg ' $n$ witskrif waarin duideliker beleidsrigtings aangedui word vir bespreking en waarin konsepvoorstelle vir wetgewing reeds vervat is. Werkswinkels word deurgaans oor die betrokke aangeleenthede deur deskundiges buite die parlement gehou.

- Hierna word die konsepwetgewing ter tafel gelê en in die Parlement gedebatteer. 'n Portefeuljekomitee word dan aangewys, bestaande uit lede van die Parlement wat deur die onderskeie politieke partye aangewys word onder voorsitterskap van die minister onder wie die saak ressorteer.

- Die portefeuljekomitee nooi alle belanghebbendes uit die samelewing uit om voorleggings te doen oor die saak vanuit hulle perspektief. Skriftelike voorleggings aan die sekretariaat van die

3 Aangesien dié dokument opgestel deur dr. Ben Du Toit nie gepubliseer is nie, word die proses wat hy beskryf, breedvoerig uiteengesit. 
komitee word opgevolg deur 'n uitnodiging aan die betrokke belangegroepe om op 'n gegewe datum hulle voorleggings aan die komitee te maak.

- Tydens die voorleggings aan die komitee kan komiteelede vrae ter verduideliking van hulle standpunt aan die indieners stel.

- Die portefeuljekomitee oorweeg dan die voorleggings in komitee met die oog op die formulering van wetgewing vir voorlegging aan die Parlement. Wanneer die komitee agterkom dat daar groot ontevredenheid onder die hoofrolspelers en meningsvormers oor die onderhawige saak is, kan die komitee verdere voorleggings aanvra.

- Die wetgewing word dan in die Parlement voorgelê vir 'n tweede debat waarna tot stemming oorgegaan word.

- Indien die uitslag van die stemming positief vir die nuwe wetgewing is, word dit bekragtig wanneer die president van die land dit onderteken.

- Alle wetgewing word aan die grondwet gemeet en indien 'n party of belangegroep steeds ontevrede is, en meen dat die wetgewing strydig is met bepaalde regte wat in die Grondwet verskans word, kan appèl aangeteken word na die Grondwetlike Hof.

Dit moet verder in gedagte gehou word dat alle wette na 1994, met die aanvaarding van die nuwe Grondwet, in beginsel amendeerbaar is. Nadat wetgewing goedgekeur is, gaan die proses voort om wette sodanig te verbeter dat dit groter ooreenstemming met die vereistes van die Grondwet toon en prakties meer uitvoerbaar is.

In die lig daarvan dat die burgerlike gemeenskap in ooreenstemming met die beginsel van deelnemende demokrasie by wetgewende en beleidmakende prosesse betrek word, word voorgestel dat 'n gereformeerde ekumeniese moniteringsliggaam van wetgewing tot stand gebring moet word om betrokke te raak by openbare beleidsvorming.

\subsection{Waarom gereformeerd?}

Die vraag kan inderdaad gevra word: Waarom juis gereformeerd? Du Toit (2003:4) wys tereg daarop dat die grootte van die belangegroepe wat voorleggings aan die portefeuljekomitee maak, 'n rol speel in die gewig wat hulle standpunt dra. Dit maak samewerking tussen verskillende geloofsgroepe noodsaaklik. Die totstandkoming van 'n gereformeerde moniteringsliggaam sluit nie die moontlikheid van ekumeniese samewerking met ander ge- 
loofsgroepe uit nie. Een van die doelwitte van 'n gereformeerde moniteringsliggaam behoort juis te wees om samewerking met ander belangegroepe en kerklike groepe (spesifiek die bestaande kantore van die Suid-Afrikaanse Raad van Kerke en die RoomsKatolieke kerk) na te streef. Alhoewel ekumeniese samewerking altyd die ideaal behoort te wees, is realisme ook noodsaaklik. Enersyds is daar aangeleenthede wat soms vir gereformeerdes belangrik sal wees, maar nie noodwendig vir ander godsdienstige groepe nie. Andersyds verskil die gereformeerde etiek en lewensen wêreldbeskouing in verskeie opsigte van die ekumeniese beweging en die Rooms-Katolieke Kerk se lewens- en wêreldbeskouing. Spesifieke gereformeerde getuienis kan soms wenslik en vanuit 'n openbare oogpunt selfs verrykend wees.

\subsection{Samestelling}

Kerke vanuit die volle reformatoriese spektrum behoort by die moniteringsliggaam betrokke te wees. Veral die insette van swart kerke sal baie belangrik wees. Hoe groter en meer pluralisties die gemeenskap wat verteenwoordig word, hoe sterker sal die seggenskap van die liggaam wees in die wetskrywende proses. Die Konvent van Reformatoriese Kerke kan hierin 'n goeie aanknopingspunt wees. Vyftien kerkgemeenskappe van reformatoriese inslag is tans by die Konvent betrokke.

Die moniteringsliggaam kan uit twee bene bestaan, naamlik:

- 'n Adviesgroep vir parlementêre sake wat saamgestel is uit verteenwoordigers van al die verskillende kerke (die huidige adviesgroep in 'n uitgebreide hoedanigheid).

- 'n Uitvoerende komitee wat bestaan uit voltydse personeel van twee of drie lede (verkieslik met een regsgeleerde).

Die taak van die uitvoerende komitee kan wees om so vroeg as moontlik relevante wetgewing wat geprosesseer word te identifiseer, om die adviesgroep byeen te roep en te raadpleeg, om in opdrag van die adviesgroep samewerking met ander kerkgroepe of sosiale groepe te soek, en om namens die verskillende gereformeerde kerke voorleggings aan die portefeuljekomitee van die parlement te maak. Die uitvoerende komitee kan verder as 'n fasiliteerder optree deur kerke in te lig oor nuwe wetgewing of wetgewing wat geamendeer word, deur werkswinkels aan te bied en deur navrae uit verskillende oorde te hanteer. 
Die taak van die adviesgroep sal wees om relevante wetgewing in die lig van die Skrif en die gereformeerde etiek te beoordeel en opdragte aan die uitvoerende komitee deur te gee.

\subsection{Kerkregtelike werkswyse}

Die gereformeerde kerkregtelike beginsel dat geen kerk oor 'n ander heerskappy moet voer nie, behoort as 'n belangrike beginsel vir 'n gereformeerde ekumeniese moniteringsliggaam te dien (art. $84 \mathrm{KO}$ van die GKSA). Standpunte van deelnemende kerke moet nie op ander afgedwing word nie. Besluite wat die adviesgroep neem, behoort konsensusbesluite te wees. Die uitvoerende komitee behoort geen selfstandige handelingsbevoegdheid te besit nie, maar kan alleen optree namens lidkerke wat 'n spesifieke en goed omskrewe opdrag aan die komitee deurgee (vgl. art. $48 \mathrm{KO}$ van die GKSA; GKSA, 1998). In praktyk sal dit beteken dat die uitvoerende komitee nie namens die ekumeniese liggaam as sodanig nie, maar wel namens die verskillende lidkerke wat 'n bepaalde voorlegging steun, optree.

Die lede van die adviesgroep behoort te bestaan uit afgevaardigdes/ deputates vanuit die verskillende kerke wat van hulle kerke die mandaat ontvang om wetgewing in die lig van die Skrif en die gereformeerde etiek te monitor (vgl. art. $48 \mathrm{KO}$ van die GKSA; GKSA, 1998).

\subsection{Praktiese haalbaarheid}

Die aanstelling van twee of drie voltydse personeellede om as uitvoerende komitee te dien, die moontlike huur van 'n kantoor naby die Parlement en die hou van vergaderings (moontlik telefoon- of internetvergaderings) sal ongeveer tussen R800 000 en R1 miljoen per jaar kos. Op die oog af lyk dit onbekostigbaar. Indien 15 verskillende kerkgemeenskappe hulleself egter bereid verklaar om R1 p.j. per belydende lidmaat by te dra by wyse van ramings of kollektes is die doelwit maklik bereikbaar.

\section{Konklusie}

Die kerk het in sy profetiese getuienis die koninkryk van God as rigpunt. Die grondliggende gedagte van die koninkryk is dat Christus Koning is oor die kerk en die ganse skepping (vgl. Du Plooy, 2003:492). Niks val buite die domein van Christus se regering nie. Daarom is dit belangrik dat reformatoriese kerke in Suid-Afrika op 'n sigbare wyse saam met gelowiges in hulle eie invloedsfere poog om 
ook die proses van openbare beleidsvorming aan die lig van die Skrif te onderwerp. Die nuwe staatkundige bedeling gee aan kerke 'n unieke geleentheid om hulle roeping teenoor die koninkryk van God na te kom. Deur 'n gereformeerde ekumeniese liggaam wat wetgewing monitor kan kerke vanuit die reformatoriese tradisie in dialoog met ander sosiale groepe 'n verskil in die beleidmakende prosesse van die land maak. Die sukses van die evangeliese kerke in die Verenigde State van Amerika in die monitering van wetgewing is ' $n$ treffende voorbeeld van die invloed wat so 'n liggaam kan uitoefen.

\section{Geraadpleegde bronne}

ACKERMANN, L.W.H. 2002. Some reflections on the Constitutional Court's freedom of religion jurisprudence. Nederduitse Gereformeerde Teologiese Tydskrif, 43(1 \& 2):177-184, Maart \& Junie.

BASSON, D. 1995. South-Africa's interim constitution: text and notes. Rev. ed. Kenwyn: Juta.

COETZEE, G. 1995. Human rights: the start of a new culture. RSA Review/Oorsig, 8(2):30-40, Jan/Feb.

COCHRANE, J.R. 1997. Theological reflection on public policy. The church and the reconstruction of South African society. Journal of Theology for Southern Africa, 97:1-15.

DE VILLIERS, D.E. 1999. Challenges to Christian ethics in the present South African society. Scriptura, 69:75-91.

DUBOW, S. 1989. Racial segregation and the origins of Apartheid in SouthAfrica, 1919-1936. London: MacMillan.

DU PLESSIS, L.M. 1994. The protection of religious rights in South Africa's transitional constitution. Koers, 59(2):151-168.

DU PLOOY, A. le R. 2003. Die Gereformeerde Kerke in Suid-Afrika 1859-2002: die vervulling van 'n roeping in die belang van die koninkryk van God? In die Skriflig, 485-505, Sept.

DU TOIT, B. 2003. Voorlegging aan die taakspan vir herstrukturering van die Algemene Sinode van die Nederduitse Gereformeerde Kerk van SuidAfrika. Ongepubliseer.

EYBERS, G.W. 1918. Select constitutional documents illustrating South African history 1795-1910. London: Routledge.

GEREFORMEERDE KERKE IN SUID-AFRIKA. 1964. Handelinge van die vyf en dertigste sinodale vergadering van die Gereformeerde Kerk in SuidAfrika. Potchefstroom: Potch Herald.

GEREFORMEERDE KERKE IN SUID-AFRIKA. 1976. Handelinge van die nege en dertigste sinode van die Gereformeerde Kerke in Suid-Afrika. Potchefstroom: Potch Herald.

GEREFORMEERDE KERKE IN SUID-AFRIKA. 1979. Handelinge van die veertigste sinode te Potchefstroom. Potchefstroom: Potch Herald.

GEREFORMEERDE KERKE IN SUID-AFRIKA. 1988. Handelinge van die drie en veertigste Nasionale Sinode. Potchefstroom: Potch Herald. 
GEREFORMEERDE KERKE IN SUID-AFRIKA. 1991. Handelinge van die vier en veertigste Nasionale Sinode te Potchefstroom. Potchefstroom: Potch Herald.

GEREFORMEERDE KERKE IN SUID-AFRIKA. 1994. Handelinge van die vyf en veertigste Nasionale Sinode te Potchefstroom. Potchefstroom: Potch Herald.

GEREFORMEERDE KERKE. 1998. Kerkorde van die Gereformeerde kerke in Suid-Afrika soos gewysig deur die verskillende sinodes. Potchefstroom: Administratiewe Buro.

GEREFORMEERDE KERKE IN SUID-AFRIKA. 2003. Agenda van die agt-en veertigste nasionale sinode te Potchefstroom. Potchefstroom: Administratiewe Buro.

GILDENHUYS, J.L. 2002. An assesment of constitutional guarantees of religious rights and freedoms in South Africa. Stellenbosch: Universiteit

GKSA van Stellenbosch. (LL.D.-proefskrif.)

kyk Gereformeerde Kerke in Suid-Afrika

GRONDWET

kyk Suid-Afrika

GUSTAFSON, J.M. 1988. An analysis of church and society social ethic writings. Ecumenical Review, 40(2):267-278, April.

HENRARD, K. 2001. The accommodation of religious diversity in South Africa against the background of the centrality of the equality principle in the new constitutional dispensation. Journal of African Law, 45(1);51-72.

KONVENT VAN REFORMATORIESE KERKE IN SUIDER-AFRIKA. 1998. Grondslag en funksionering van die Konvent van reformatoriese kerke in Suider-Afrika. Ongepubliseerd.

KUITERT, H.M. 1985. Everything is politics but politics is not everything. A theological perspective on faith and politics. Ten Have: Baarn.

LE ROUX, F. 1994. Die beginsels van 'n regstaat. RSA Review/Oorsig, 7(2): 56-61, Maart.

NATHAN, L. 1997. The bill of rights: it protects our human rights and prevents the abuse of power by the state. Salut, 4(10), Oktober.

PIETERSE, M. 2000. Constitutional protection of religious rights. CILSA, XXXIII:300-317.

RES (Reformed Ecumenical Synod). 1983. Testimony on human rights. Grand Rapids, Mich.: RES.

SACC (South African Council of Churches). 2003. About the SACC parliamentary office. htpp//www.sacc-ct.org.za [14 November 2003].

SMIT, D. \& DE VILLIERS, D.E. 1995. Met watter gesag sê u hierdie dinge? Opmerkings oor kerklike dokumente oor die openbare lewe. Skrif en Kerk, 16(1):39-57.

SMIT, D. 1996a. Oor die kerk as unieke samelewingsverband. Tydskrif vir Geesteswetenskappe, 119-129, Junie.

SMIT, D. 1996b. Oor die unieke openbare rol van die kerk. Tydskrif vir Geesteswetenskappe, 190-204, Mei.

SUID-AFRIKA. 1957. Wysigingswet op Swart Wetgewing, no. 36 van 1957. Pretoria: Staatsdrukker.

SUID-AFRIKA. 1967. Wet op Nasionale Onderwysbeleid, no. 39 van 1967. Pretoria: Staatsdrukker. 
SUID-AFRIKA. 1974. Wet op Publikasies, no. 42 van 1974. Pretoria: Staatsdrukker.

SUID-AFRIKA. 1977. Wet op die verbod op die vertoon van rolprente op Sondae en publieke vakansiedae, no. 16 van 1977. Pretoria: Staatsdrukker.

SUID-AFRIKA. 1977. Wet op die verbod op die vertoon van rolprente op Sondae en publieke vakansiedae, no. 16 van 1977. Pretoria: Staatsdrukker.

SUID-AFRIKA. 1979. Wet op onderwys en opleiding, no. 90 van 1979. Pretoria: Staatsdrukker.

SUID-AFRIKA. 1996. Constitution of the Republic of South-Africa as adopted by the Constitional Assembly on 8 May 1996 and as amended on 11 October 1996. (B34B-96.) (ISBN: 0-260-20716-7.)

SUID-AFRIKA. 1996. Wet op keuse oor die beëindiging van Swangerskap, no. 92 van 1996. Pretoria: Staatsdrukker.

THOMPSON, L. 1990. A history of South Africa. London/New Haven: Yale.

TRUTH AND RECONCILIATION COMMISION OF SOUTH-AFRICA. 1998. Report 1-5. Kaapstad: TRC/Juta (afgekort as TRC).

VAN DER VYVER, J.D. 1998. Constitutional perspective of church-state relations in South Africa. (Referaat gelewer te Salt Lake City by konferensie oor kerk-staatverhoudinge van 4-6 Oktober 1998). Ongepubliseer.

VAN WYK, J.H. 1991. Moraliteit en verantwoordelikheid: opstelle oor politieke etiek. Potchefstroom: PU vir CHO.

VENTER, F. 1995. Die ontstaan van staatkundige stelsels toegepas op die kontemporêre Suid-Afrikaanse staat. Tydskrif vir Geesteswetenskappe, 35(1):128-139, Maart.

VENTER, F. 1997. Aspects of the South-African Constitution of 1996: an African democratic and social federal Rechtstaat. Heidelberg Journal of International Law/Zeitschrift für auslandisches Recht öffentliches Recht und Völkerrecht, 57(1):52-82.

VENTER, F. 1998. The protection of cultural, linguistic and religious rights: the framework provided by the Constitution of the Republic of South Africa, 1996. Suid-Afrikaanse Publieke Reg, 13:438-459.

VORSTER, N. 2002. Kerk en menseregte binne 'n regstaat. Die profetiese roeping van die kerk ten opsigte van die vestiging van 'n etos van menseregte in Suid-Afrika. Potchefstroom: PU vir CHO. (Th.D.-proefskrif.) Gepubliseer as Kerk en menseregte binne 'n regstaat. Potchefstroom: PSP.

VORSTER, N. 2003. Pastoraal sensitiewe benadering van homoseksualiteit. Resensie. Koers, 68(1):109-115.

WAARHEID- EN VERSOENINGSKOMMISSIE kyk Truth and Reconciliation Commission

WARC (World Alliance of Reformed Churches). 1976. Theological basis of human rights. Geneva: WARC.

WIHER, H. 2002. Understanding shame and guilt as a key to cross-cultural Christian ministry - an elenctical study. Potchefstroom: $\mathrm{PU}$ vir $\mathrm{CHO}$. (Th.D. thesis.)

WITTE, J. 1993. The South African experiment in religious human rights. What can be learned from the American experience. Journal for Juridical Science, 1:1-30. 


\section{Hofsake}

State v Lawrence 1997(1)BCLR 1348 (CC).

Christian Education South Africa v Minister of Education 2000(1) BCLR 1051(CC)

\section{Wette}

Wysigingswet op Swart Wetgewing (36/57).

Wet op Publikasies (42/74).

Wet op Nasionale Onderwysbeleid (39/67).

Wet op Onderwys en Opleiding (90/79).

Wet op die Vertoon van Rolprente op Sondae en Openbare Vakansiedae (16/77).

Wet op Keuse oor die Beeïndiging van Swangerskap (92/96).

\section{Key concepts:}

constitutional state

monitoring

public witness

religious rights

Kernbegrippe:

godsdiensregte

monitering

openbare getuienis

regstaat 
